\title{
Yusuf Trilogy 3-DVD SET
}

\author{
By Jan Uhde
}

Spring 2011 Issue of KINEMA

Semih Kaplanoğlu is today a pillar of the recent revival of Turkish cinema, its "second wave" as some call it. Together with Nuri Bilge Ceylan (Distant) and the younger German-Turkish Fatih Akın (Head On), Kaplanoğlu has helped to propel the cinema of his country to the forefront of film's creative ferment.

Kaplanoğlu's position has been reinforced by his Yusuf Trilogy (2007-2010), the latest instalment of which, Honey, was awarded the Golden Bear at the 2010 Berlinale. Even before this, the director was a familiar face at international festivals - his Yusuf trilogy having garnered over a dozen of festival prizes and awards.

The semi-autobiographical segments, Egg (Yumurta, 2007), Milk (Süt, 2009) and Honey (Bal, 2010) were, from the perspective of their hero Yusuf, released "backwards" - the first release, Egg, portrayed Yusuf in his thirties, Milk, when he was a teenager and in the most recent, Honey, as a small boy. In Honey, the director employs a realistic, restrained, almost minimalist style with limited dialogue, entirely abstaining from non-diegetic music, dramatics and sentimentality. Instead, viewers are treated to honest cinema filled with beautifully framed, lyrical imagery - as in the boy's attempts to catch the full moon dancing in a pail of water. Without doubt, this DVD set is a triple treat for any film lover.

\section{Author Information}

Jan UHDE is Professor Emer. (Film Studies) at the University of Waterloo, Ontario, Canada. Born in Brno, Czech Republic. Graduated (MA) from the Faculty of Arts, Masaryk University, Brno; PhD received at the University of Waterloo, Ontario, Canada. He taught at the University of Waterloo (1970-2012) where he founded a General and Honours BA program in Film Studies at the Department of Fine Arts.

Publications: Latent Images: Film in Singapore Second edition, with Yvonne Ng Uhde (Ridge Books, National University Press of Singapore, 2010); Latent Images: Film in Singapore, with Yvonne Ng Uhde (Oxford University Press, 2000); Latent Images: Film in Singapore CD-ROM (2003, co-author); Vision and Persistence: Twenty Years of the Ontario Film Institute (University of Waterloo Press, 1990) and Ontario Film Institute Programming Activities Index 1969-1989 (Toronto: Ontario Science Centre, 1990). He co-edited the Place in Space: Human Culture in Landscape (Proceedings from the Second International Conference of the Working Group "Culture and Landscape" of the International Association of Landscape Ecology, Pudoc Scientific Publishers, Wageningen, Holland, 1993). Jan Uhde has published articles and reviews in several countries (including Canada, USA, Germany, Italy), participated in international juries at film festivals and presented papers at international conferences in North America and Europe. In 1998/99, he was a visiting researcher at the School for Film and Media Studies, Ngee Ann Polytechnic, Singapore.

His professional and research interests focus on Singapore cinema; the identification and distancing mechanisms of the film viewer; the non-authored modifications and manipulation of films; and specific aspects of film history, including the Central European cinema.

He founded KINEMA in 1993. 


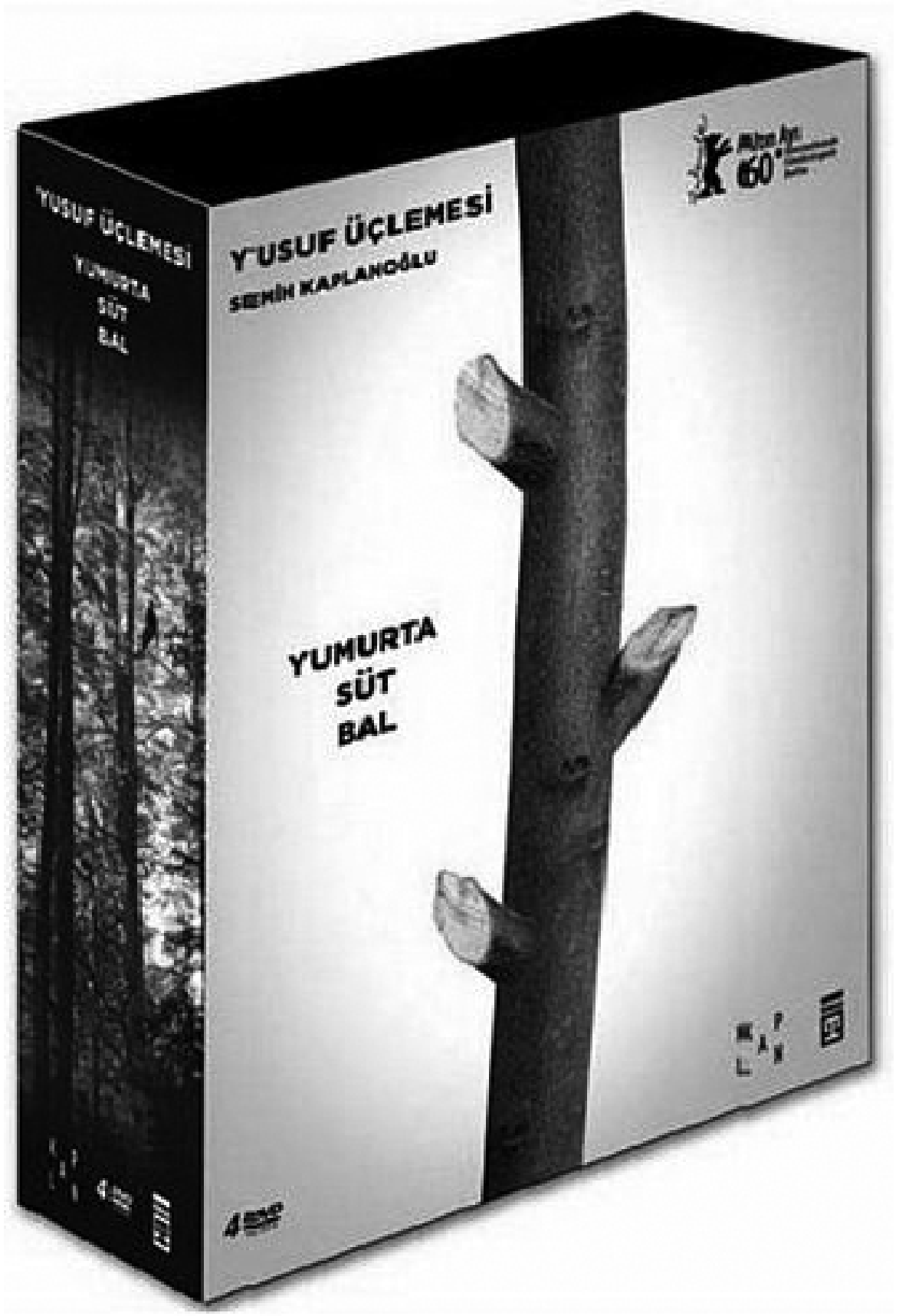

Figure 1: Egg (Yumurta, 2007), Milk (Süt, 2009) and Honey (Bal, 2010), directed by Semih Kaplanoğlu, Turkey. Colour, widescreen, English subtitles, PAL Region 2. Supplement disc (in Turkish only). Production: Kaplan Film. List price: approx. USD 60.00. 